\title{
A Literature Review of GP Knowledge and Understanding of ME/CFS: A Report from the Socioeconomic Working Group of the European Network on ME/CFS (EUROMENE)
}

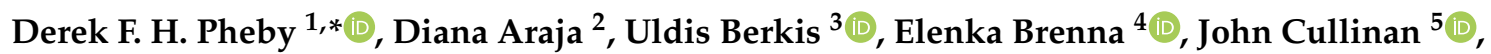

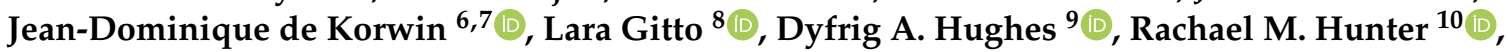 \\ Dominic Trepel ${ }^{11,12}$ and Xia Wang-Steverding ${ }^{13}$ (i)
}

\section{check for}

updates

Citation: Pheby, D.F.H.; Araja, D.; Berkis, U.; Brenna, E.; Cullinan, J.; de Korwin, J.-D.; Gitto, L.; Hughes, D.A.; Hunter, R.M.; Trepel, D.; et al. A Literature Review of GP Knowledge and Understanding of ME/CFS: A Report from the Socioeconomic Working Group of the European Network on ME/CFS (EUROMENE). Medicina 2021, 57, 7. https://dx.doi.org/10.3390/ medicina57010007

Received: 24 November 2020 Accepted: 21 December 2020 Published: 24 December 2020

Publisher's Note: MDPI stays neutral with regard to jurisdictional claims in published maps and institutional affiliations.

Copyright: (C) 2020 by the authors. Licensee MDPI, Basel, Switzerland. This article is an open access article distributed under the terms and conditions of the Creative Commons Attribution (CC BY) license (https: / / creativecommons.org/ licenses/by/4.0/).
1 Society and Health, Buckinghamshire New University, High Wycombe HP11 2JZ, UK

2 Department of Dosage Form Technology, Faculty of Pharmacy, Riga Stradins University, Dzirciema Street 16, LV-1007 Riga, Latvia; diana.araja@rsu.lv

3 Institute of Microbiology and Virology, Riga Stradins University, Dzirciema Street 16, LV-1007 Riga, Latvia; Uldis.Berkis@rsu.lv

4 Department of Economics and Finance, Università Cattolica del Sacro Cuore, Largo Agostino Gemelli 1, 20123 Milan, Italy; elenka.brenna@unicatt.it

5 School of Business \& Economics, National University of Ireland Galway, University Road, H91 TK33 Galway, Ireland; john.cullinan@nuigalway.ie

6 Internal Medicine Department, University of Lorraine, 34, cours Léopold, CS 25233, CEDEX F-54052 Nancy, France; jean-dominique.dekorwin@univ-lorraine.fr

7 University Hospital of Nancy, Rue du Morvan, 54511 Vandœuvre-Lès-Nancy, France

8 Department of Economics, University of Messina, Piazza Pugliatti 1, 98122 Messina, Italy; lara.gitto@unime.it

9 Centre for Health Economics \& Medicines Evaluation, Bangor University, Bangor LL57 2PZ, UK; d.a.hughes@bangor.ac.uk

10 Institute of Epidemiology \& Health, Royal Free Medical School, University College London, London NW3 2PF, UK; r.hunter@ucl.ac.uk

11 School of Medicine, Trinity College Dublin, College Green, D02 PN40 Dublin 2, Ireland; trepeld@tcd.ie

12 Global Brain Health Institute, School of Medicine, Trinity College Dublin, College Green, D02 PN40 Dublin 2, Ireland

13 Warwick Medical School, University of Warwick, Coventry CV4 7AL, UK; xiasteverding@gmail.com

* Correspondence: derekpheby@btinternet.com

Abstract: Background and Objectives: The socioeconomic working group of the European myalgic encephalomyelitis/chronic fatigue syndrome (ME/CFS) Research Network (EUROMENE) has conducted a review of the literature pertaining to GPs' knowledge and understanding of ME/CFS; Materials and Methods: A MEDLINE search was carried out. The papers identified were reviewed following the synthesis without meta-analysis (SWiM) methodology, and were classified according to the focus of the enquiry (patients, GPs, database and medical record studies, evaluation of a training programme, and overview papers), and whether they were quantitative or qualitative in nature; Results: Thirty-three papers were identified in the MEDLINE search. The quantitative surveys of GPs demonstrated that a third to a half of all GPs did not accept ME/CFS as a genuine clinical entity and, even when they did, they lacked confidence in diagnosing or managing it. It should be noted, though, that these papers were mostly from the United Kingdom. Patient surveys indicated that a similar proportion of patients was dissatisfied with the primary medical care they had received. These findings were consistent with the findings of the qualitative studies that were examined, and have changed little over several decades; Conclusions: Disbelief and lack of knowledge and understanding of ME/CFS among GPs is widespread, and the resultant diagnostic delays constitute a risk factor for severe and prolonged disease. Failure to diagnose ME/CFS renders problematic attempts to determine its prevalence, and hence its economic impact.

Keywords: ME/CFS; myalgic encephalomyelitis; chronic fatigue syndrome; primary care; GP knowledge and understanding 


\section{Introduction}

Myalgic encephalomyelitis/chronic fatigue syndrome (ME/CFS) is a poorly understood, serious, complex, multi-system disorder, characterized by symptoms lasting at least six months, with severe incapacitating fatigue not alleviated by rest, and other symptoms, many autonomic or cognitive in nature, including cognitive dysfunction, sleep disturbances, muscle pain, and post-exertional malaise, which lead to marked reductions in functional activity and quality of life [1-3]. Symptomatology, severity and disease progression are all very variable. ME/CFS is most common between the ages of 20 to 50 years, but it can affect all age groups. Around three quarters of patients are female [4-6]. There are no Europe-wide prevalence data, but there is a commonly held belief that there are some 250,000 sufferers in the U.K. [7]. If this is correct, there may be some two million patients in Europe as a whole.

The European ME/CFS Research Network (EUROMENE) was established to promote collaborative research on the condition across Europe. It is currently in receipt of EU funding from the Collaboration on Science and Technology Association (COST, https:/ / www.cost.eu) to support network activities. It seeks to review the current state of the art and to identify gaps in knowledge of ME/CFS. EUROMENE also aims to shed light on the overall burden of disease, and also to investigate possible biomarkers, diagnosis and treatment [8].

Previous work by the socioeconomic working group of EUROMENE identified widespread failure by GPs to diagnose ME/CFS as an important factor contributing to underestimation of the incidence and prevalence of the illness, and hence of its economic impact [9]. The group conducted a pilot survey among EUROMENE participants to assess the position regarding GP diagnoses of ME/CFS [10]. The survey findings suggested that under-diagnosis in primary care was a Europe-wide problem, and that estimates of the public health burden of the illness, even where these exist, are therefore likely to underestimate substantially its true prevalence.

A systematic review of qualitative studies published in 2013 and concerned with barriers to the diagnosis and management of CFS / ME in primary care identified 21 studies. This review demonstrated a limited understanding of ME/CFS by GPs [11]. We conducted a comprehensive literature review with the aim of assessing whether primary care doctors' awareness, understanding and acceptance of ME/CFS as a disease has changed in the intervening years.

\section{Materials and Methods}

A MEDLINE search was carried out, covering the period from 1946 until 20 August 2020. The inclusion criteria were focuses on general practice, family practice, primary care or primary health care, and myalgic encephalomyelitis or chronic fatigue syndrome (including ME/CFS, CFS/ME, and post-viral fatigue syndrome). Exclusions were papers not addressing GP attitudes, knowledge or understanding of ME/CFS or any of its synonyms.

The papers were sorted into categories following the synthesis without meta-analysis (SWiM) methodology. Categories were defined on the basis of the focus of the enquiry (patients, GPs, database and medical record studies, evaluation of a training programme, and overview papers), and whether the studies were quantitative or qualitative in nature. These are summarised in Table 1 below. One of the papers was the review referred to above [11].

Table 1. Search Strategy.

\begin{tabular}{ccc}
\hline Step & Description & No. Records \\
\hline 1 & General Practice or family practice & 75,004 \\
\hline 2 & limit 1 to abstracts & 35,740 \\
\hline 3 & Primary care, or primary health care & 133,124 \\
\hline 4 & limit 3 to abstracts & 104,892 \\
\hline 5 & 2 or 4 & 129,775 \\
\hline
\end{tabular}


Table 1. Cont.

\begin{tabular}{ccc}
\hline Step & Description & No. Records \\
\hline 6 & Myalgic encephalomyelitis, or fatigue syndrome, chronic & 5606 \\
\hline 7 & limit 6 to abstracts & 3936 \\
\hline 8 & 5 and 7 & 176 \\
\hline 9 & After exclusions (because not conforming to inclusion criteria) & 33 \\
\hline 10 & After exclusions (because of unavailability of full texts) & 30 \\
\hline
\end{tabular}

\section{Results}

3.1. Search Strategy

3.1.1. Implementation

The search strategy and its outcomes are summarised in Table 1 and Figure 1 below:
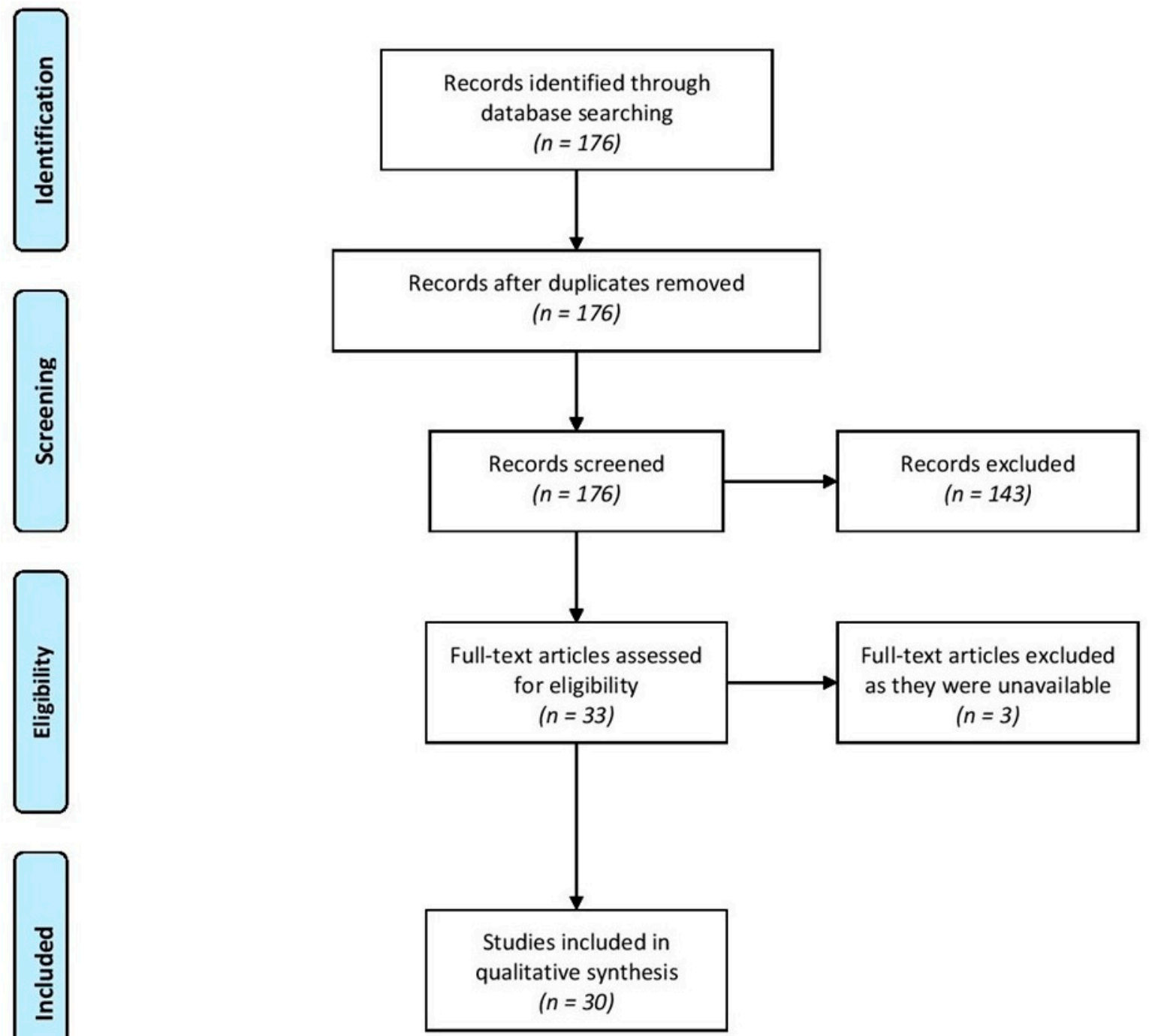

Figure 1. PRISMA Diagram. 
At step 9, 143 papers were excluded, either because the focus was not primary care, or because they were not about ME/CFS, or because, although they did concern ME/CFS in primary care, they did not address knowledge or understanding of the condition. The papers identified were extremely heterogeneous with respect to the populations studied, research questions addressed, and methodologies followed, as to preclude any form of meta- synthesis or meta-analysis. Consequently, the synthesis without meta-analysis (SWiM) methodology, which was developed specifically to ensure an adequate standard of review in such circumstances, was utilised [12].

\subsubsection{Papers Identified}

The papers identified in the MEDLINE search were considered in detail within the categories identified in Table 2.

Table 2. Summary of papers identified.

\begin{tabular}{cc}
\hline Type of Study & No. Papers Identified ${ }^{*}$ \\
\hline Reviews & 1 \\
\hline GP surveys-quantitative & 7 \\
\hline Patient surveys-quantitative & 7 \\
\hline Database studies-quantitative & 2 \\
\hline Medical record review-quantitative & 1 \\
\hline Evaluation of training programme-quantitative & 1 \\
\hline GP studies-qualitative & 6 \\
\hline Patient studies-qualitative & 9 \\
\hline $\begin{array}{l}\text { Overview papers on myalgic encephalomyelitis/chronic fatigue } \\
\text { syndrome (ME/CFS) }\end{array}$ & 4 \\
\hline $\begin{array}{l}\text { * Note that the total is greater than the number identified in the MEDLINE search, because some qualitative } \\
\text { papers are included in more than one category. }\end{array}$
\end{tabular}

\subsection{Quantitative Studies}

\subsubsection{Surveys of GPs}

Seven papers were identified. Saidi and Haines (2006) distributed a postal questionnaire to GPs throughout the U.K., to assess the proportion of practices with children diagnosed with ME/CFS [13]. Of the 112 practices contacted, 62 (55\%) had diagnosed children or adolescents with chronic fatigue.

For each of the other six studies, the outcome metric was the proportion of GP respondents to questionnaires who recognised ME/CFS as a genuine clinical entity, and these are summarised in Table 3. Three of these studied GPs were in different parts of the U.K., namely, South Wales [14], Scotland [15] and south-west England [16], while the other papers were from Australia [17], the Netherlands [18] and Ireland [19]. The Australian study reported that $31 \%$ of GPs surveyed did not accept ME/CFS as a distinct syndrome [17], but we lacked a full text of this paper. 
Table 3. Acceptance in general practice of ME/CFS as a genuine clinical entity.

\begin{tabular}{|c|c|c|c|c|c|}
\hline Authors & $\begin{array}{c}\text { Year of } \\
\text { Publication }\end{array}$ & Location & Sample Size & $\begin{array}{l}\text { Principal Finding: } \% \\
\text { Respondents } \\
\text { Accepting Existence } \\
\text { of ME/CFS as a } \\
\text { Genuine Clinical } \\
\text { Entity }\end{array}$ & Definition of Outcome \\
\hline $\begin{array}{c}\text { Ho-Yen DO, } \\
\text { McNamara I. [15] }\end{array}$ & 1991 & Scotland & 178 & 71 & $\begin{array}{l}\text { Response to question as to } \\
\text { whether respondent } \\
\text { accepted the existence of } \\
\text { chronic fatigue syndrome, } \\
\text { requiring 'yes', 'no' or } \\
\text { 'undecided' response. }\end{array}$ \\
\hline $\begin{array}{c}\text { Fitzgibbon EJ, } \\
\text { Murphy D, O'Shea } \\
\text { Ket al. [19] }\end{array}$ & 1997 & Ireland & 118 & 58 & $\begin{array}{l}\text { Response to question: 'Do } \\
\text { you accept CFS as a distinct } \\
\text { clinical entity?', requiring } \\
\text { 'accept', 'do not accept' or } \\
\text { 'undecided' response. }\end{array}$ \\
\hline $\begin{array}{c}\text { Bazelmans E, } \\
\text { Vercoulen JH, } \\
\text { Swanink CM et al. } \\
{[18]}\end{array}$ & 1999 & Netherlands & 3881 & 99 & $\begin{array}{l}\text { Inferred from number of } \\
\text { invitees who cited disbelief } \\
\text { in the syndrome as their } \\
\text { reason for non-response }\end{array}$ \\
\hline $\begin{array}{l}\text { Thomas MA, } \\
\text { Smith AP. [14] }\end{array}$ & 2005 & South Wales & 45 & 56 & $\begin{array}{l}\text { Proportion of respondents } \\
\text { agreeing that the syndrome } \\
\text { actually exists (specific } \\
\text { question not reported) }\end{array}$ \\
\hline $\begin{array}{l}\text { Bowen J, Pheby D, } \\
\text { Charlett A, } \\
\text { McNulty C. [16] }\end{array}$ & 2005 & $\begin{array}{l}\text { South-west } \\
\text { England }\end{array}$ & 811 & 72 & $\begin{array}{l}\text { Responses agreeing or } \\
\text { strongly agreeing to } \\
\text { proposition via a 5-point } \\
\text { Likert scale }\end{array}$ \\
\hline
\end{tabular}

In the Dutch study [18] respondents were not specifically asked whether they accepted the existence of ME/CFS as a genuine clinical entity, and the proportion of GPs who reported that they did not accept ME/CFS as a genuine clinical entity was inferred from the number of those contacted who indicated, via a free text response, that this was their opinion. However, $73 \%$ of respondents reported that they had at least one patient with chronic fatigue syndrome, and $83 \%$ that they had at least one patient with post-viral fatigue syndrome.

The heterogeneous nature of populations studied, and the research methodologies utilised precluded a formal meta-analysis, but for comparison purposes we have calculated 95\% confidence intervals for the British and Irish studies which specifically enquired about the acceptance of ME/CFS as a genuine diagnosis. The higher levels of acceptance of $\mathrm{ME} / \mathrm{CFS}$ in Scotland and south-west England may demonstrate the impact of secondary referral facilities and active programmes of GP education in those areas. The results are itemised in Table 4.

There were additional findings of relevance in the studies examined. Bowen et al. [16] found that only $52 \%$ of respondents expressed confidence in their ability to diagnose the condition, and $59 \%$ in their ability to manage it. Sixty-eight percent of respondents to the study in South Wales had diagnosed the condition [14]. In the Irish study, 78\% of respondents had patients with chronic debilitating fatigue in their practices [19].

These studies were published over a fourteen-year period, and are consistent in demonstrating that a substantial proportion of GPs, which changed little over that time, did not accept ME/CFS as a genuine clinical entity. 
Table 4. Acceptance by GPs of ME/CFS—summary statistics.

\begin{tabular}{cccc}
\hline \multirow{2}{*}{ Reference } & \multicolumn{2}{c}{ Respondents Accepting ME/CFS as Genuine } & \multirow{2}{*}{$\begin{array}{c}\text { 95\% Confidence } \\
\text { Diagnosis }\end{array}$} \\
\cline { 2 - 3 } & No./Sample Size & $\%$ & \\
\hline $\begin{array}{c}\text { Ho-Yen and } \\
\text { McNamara [15] }\end{array}$ & $127 / 178$ & 71.0 & $33.0-47.2$ \\
\hline Fitzgibbon et al. [19] & $68 / 118$ & 58.0 & $48.6-66.2$ \\
\hline Thomas and Smith [14] & $25 / 45$ & 56.0 & $41.1-69.1$ \\
\hline Bowen et al. [16] & $584 / 811$ & 72.0 & $68.8-75.0$ \\
\hline TOTAL & $804 / 1152$ & 69.8 & $67.1-72.4$ \\
\hline
\end{tabular}

\subsubsection{Surveys of ME/CFS Patients}

Seven papers were identified in this section, but three could not be included in the overall comparative analysis, one for the lack of a full text, and the others for absence of relevant numerical information. The first of these, a Belgian study of 177 patients with different GPs, attending a tertiary clinic, found that only $35 \%$ of respondents thought that their GPs had experience of the condition, and only $23 \%$ felt their GP had sufficient knowledge to treat it [20]. Another Belgian study of 155 patients with ME/CFS recruited via primary care practitioners reported that $43 \%$ of subjects self-assessed as having interpersonal problems with their GPs. A disparity with physician assessments was asserted, and the authors concluded that this disparity had to be seen in the context of previous research, demonstrating that patients with ME/CFS tended to feel misunderstood and disrespected. However, this disparity was not reported numerically [21]. Finally, a French report on 231 participants in a clinical trial undertaken in general practice found a tendency in primary care to attribute fatigue to somatic causes in cases with more reported symptoms. They attributed this to a predilection not to entertain somatic explanations of mild or moderate fatigue, but this could not be quantified from the information presented [22].

The remaining four papers are summarised in Table 5. Three of them, from Norway, are interrelated [23-25], and it can be noted that, although the outcome measures in these studies were not precisely the same as that in an American study by Jason et al. [26], and the populations studied and the modes of selection of participants were different, the proportions of respondents expressing reservations about aspects of the quality of primary care were similar in magnitude.

Table 5. Patients' opinions about GP care of people with ME/CFS.

\begin{tabular}{|c|c|c|c|c|c|c|}
\hline \multirow{2}{*}{ Authors } & \multirow{2}{*}{$\begin{array}{c}\text { Year of } \\
\text { Publication }\end{array}$} & \multirow{2}{*}{ Location } & \multirow{2}{*}{ Sample Size } & \multirow{2}{*}{$\begin{array}{c}\text { Source of } \\
\text { Recruitment }\end{array}$} & \multicolumn{2}{|c|}{ Principal Relevant Outcome Measure } \\
\hline & & & & & Description & Numerical Value \\
\hline $\begin{array}{l}\text { Jason LA; } \\
\text { Ferrari JR; } \\
\text { Taylor RR; } \\
\text { Slavich SP; } \\
\text { Stenzel CL } \\
\quad \text { [26] }\end{array}$ & 1996 & U.S.A. & 1073 & $\begin{array}{l}\text { Self-selected } \\
\text { respondents to } \\
\text { a survey } \\
\text { published in } \\
\text { the CFIDS } \\
\text { Chronicle. }\end{array}$ & $\begin{array}{l}\text { \% respondents } \\
\text { reporting a need for } \\
\text { better education of } \\
\text { health care } \\
\text { professionals } \\
\text { (including in primary } \\
\text { care) about ME/CFS }\end{array}$ & 65 \\
\hline $\begin{array}{l}\text { Hansen AH; } \\
\text { Lian OS [23] }\end{array}$ & 2016 & Norway & 488 & $\begin{array}{l}\text { Norwegian ME } \\
\text { Association } \\
\text { (cross-sectional } \\
\text { survey) }\end{array}$ & $\begin{array}{ll}\text { \% respondents } \\
\text { reporting poor } \\
\text { continuity of GP care: } \\
\text { - } \quad \text { Informational } \\
-\quad \text { Management } \\
-\quad \text { Relational }\end{array}$ & $\begin{array}{l}35 \\
35 \\
33\end{array}$ \\
\hline
\end{tabular}


Table 5. Cont.

\begin{tabular}{|c|c|c|c|c|c|c|}
\hline \multirow{2}{*}{ Authors } & \multirow{2}{*}{$\begin{array}{c}\text { Year of } \\
\text { Publication }\end{array}$} & \multirow{2}{*}{ Location } & \multirow{2}{*}{ Sample Size } & \multirow{2}{*}{$\begin{array}{c}\text { Source of } \\
\text { Recruitment }\end{array}$} & \multicolumn{2}{|c|}{ Principal Relevant Outcome Measure } \\
\hline & & & & & Description & Numerical Value \\
\hline $\begin{array}{l}\text { Hansen AH; } \\
\text { Lian OS [24]. }\end{array}$ & 2016 & Norway & 431 & $\begin{array}{l}\text { Norwegian ME } \\
\text { Association } \\
\text { (cross-sectional } \\
\text { survey) }\end{array}$ & $\begin{array}{l}\% \text { assessing overall } \\
\text { quality of primary } \\
\text { care to be poor or } \\
\text { very poor }\end{array}$ & 61 \\
\hline $\begin{array}{c}\text { Lian OS; } \\
\text { Hansen AH } \\
\text { [25]. }\end{array}$ & 2016 & Norway & 431 & $\begin{array}{l}\text { Norwegian ME } \\
\text { Association } \\
\text { (cross-sectional } \\
\text { survey) }\end{array}$ & $\begin{array}{l}\text { \% reporting } \\
\text { satisfaction (to a } \\
\text { large extent or to } \\
\text { some extent) with GP } \\
\text { support during initial } \\
\text { phase of illness }\end{array}$ & 46 \\
\hline
\end{tabular}

\subsubsection{Other Quantitative Studies}

Other quantitative studies identified included two database studies $[27,28]$ a review of medical records [29], and an evaluation of a training programme [30].

Gallagher et al., [27] in an analysis of data from the U.K. General Practice Research Database (now the Clinical Practice Research Datalink), found that, between 1990 and 2001, there was a marked decline in diagnoses of post-viral fatigue syndrome, paralleled by increases in diagnoses of ME/CFS and fibromyalgia, suggesting that diagnostic fashion has a significant part to play in the allocation of diagnostic labels by GPs. A study based on the Norwegian Patient Register found that there were substantial delays in the primary care diagnosis of ME/CFS in children and adolescents. Three-quarters of those patients identified were initially diagnosed with weakness/general tiredness, and for nearly half of them the interval between this initial diagnosis and the definitive diagnosis of ME/CFS was over a year. A comparison with diagnoses of type 1 diabetes mellitus found that only $3.5 \%$ of patients were initially diagnosed with weakness/general tiredness, and there was no comparable diagnostic delay [28].

A comparative study of the primary care prevalence of ME/CFS in Sao Paolo and London was carried out by means of a review of medical records [29]. The overall prevalence of chronic fatigue syndrome plus unexplained chronic fatigue was similar in both countries. However, a slightly higher prevalence of chronic fatigue syndrome was apparent among the U.K. patients. The authors attributed this to a cultural factor, namely, a relative lack of recognition of chronic fatigue syndrome among Brazilian doctors, but in fact the difference in prevalence of CFS between the Brazilian and English samples was not statistically significant (prevalence: Brazil 1.6\%; U.K. 2.1\%. $p=0.09$ ).

An American study evaluated a series of five two-day "Train-the-Trainer" workshop training programmes directed towards increasing ME/CFS understanding in primary care [30]. There were marked improvements in both knowledge and self-efficacy, leading to increased confidence in making the diagnosis, but the point was made that the participants were self-selected.

\subsection{Qualitative Studies}

\subsubsection{Studies of GPs}

We identified six papers reporting qualitative studies involving GPs dating from 1993 to 2016. The earliest was from New Zealand [31], and the others were all from the U.K., the most recent four coming from the same team based in north-west England [32-36]. The papers are summarised in Table 6:

All the papers reviewed were consistent in concluding that there were substantial gaps in levels of knowledge and understanding of ME/CFS. 


\subsubsection{Studies of Patients} Table 7.

Nine papers were identified in this category. Our detailed analysis is summarised in

It will be noted that the methodologies followed were extremely heterogeneous, precluding any sort of meta-synthesis, but the overall conclusions in all cases were very similar. Concern was expressed in most cases about the lack of legitimation of the condition, and many GPs were seen as being unsympathetic and lacking in knowledge of the condition, and therefore not a good source of advice. By contrast, a good rapport with the doctor was seen to be very positive, though frequently missing.

\subsection{Overview Papers}

The final category identified in this analysis was of a small number of publications which made reference to problems of GP knowledge and understanding of the condition, but presented no empirical research. Bansal wrote a wide-ranging paper centred on the use of a simplified scoring system for the diagnosis of ME/CFS in general practice, in which he described ME/CFS as poorly understood, and refers to disagreements concerning investigation and management [37]. Wearden and Chew-Graham reviewed the evidence on the primary care treatment of ME/CFS. They acknowledged that some primary care physicians find ME/CFS hard to diagnose, but argued that early diagnosis and coherent explanation of symptoms would be of benefit [38]. Murdoch produced a straightforward, easy-to-follow guide to the diagnosis and care of patients with ME/CFS, via an illustrative clinical scenario, and asserted that ME/CFS is best managed by the patient's GP in a primary care setting [39]. Campion, in a letter to the British Journal of General Practice, stated that the biopsychosocial model of ME/CFS had caused disagreement between doctors and patients, and that doctors should respect patients, and, given our ignorance of the precise causes of the condition, show humility [40]. 
Table 6. Papers reporting qualitative studies of GPs' knowledge and understanding of ME/CFS.

\begin{tabular}{|c|c|c|c|c|c|c|}
\hline Authors & $\begin{array}{c}\text { Year of } \\
\text { Publication }\end{array}$ & Location & Methodology & GP Sample Size & Relevant Outcome Measures & Findings \\
\hline $\begin{array}{l}\text { Denz-Penhey H, } \\
\text { Murdoch JC [31] }\end{array}$ & 1993 & New Zealand & $\begin{array}{l}\text { Action research in a } \\
\text { general practice }\end{array}$ & 10 & $\begin{array}{l}\text { Identification of GP tasks } \\
\text { (illness acknowledgement, } \\
\text { symptom control, } \\
\text { recommendation of health } \\
\text { behaviours, relapse } \\
\text { prevention), and service and } \\
\text { delivery mechanisms }\end{array}$ & $\begin{array}{l}\text { The authors concluded that medical } \\
\text { models of illness were unhelpful, and } \\
\text { patients suffered as failure to legitimate } \\
\text { their conditions led to denial of access } \\
\text { to medical care. They wrote: "Doctors } \\
\ldots \text { have a weighty bias towards the } \\
\text { biomedical model even when it has } \\
\text { manifestly failed to meet the needs of } \\
\text { our patients." }\end{array}$ \\
\hline $\begin{array}{c}\text { Raine R; Carter S; Sensky } \\
\text { T [32] }\end{array}$ & 2004 & England & $\begin{array}{l}\text { Focus group discussions } \\
\text { of clinical scenarios }\end{array}$ & 46 & $\begin{array}{l}\text { Thematic analysis of focus } \\
\text { group transcripts, examined } \\
\text { against field notes. }\end{array}$ & $\begin{array}{l}\text { Findings support research indicating } \\
\text { that outcomes are poorer where doctors } \\
\text { and patients disagree. Doctors' beliefs } \\
\text { could result in negative stereotyping of } \\
\text { patients with CFS, which constituted a } \\
\text { barrier to effective clinical management. }\end{array}$ \\
\hline $\begin{array}{c}\text { Chew-Graham C; } \\
\text { Dowrick C; Wearden A; } \\
\text { Richardson V; Peters S } \\
\text { [33] }\end{array}$ & 2010 & NW England & $\begin{array}{l}\text { Semi-structured } \\
\text { interviews with patients } \\
\text { participating in a } \\
\text { primary care-based } \\
\text { randomised controlled } \\
\text { trial (the FINE Trial) }\end{array}$ & 22 & $\begin{array}{l}\text { Five themes were identified: } \\
\text { defining CFS/ME, excluding } \\
\text { physical causes, potential } \\
\text { harm from the label, the role } \\
\text { of referral and moving on } \\
\text { from making the diagnosis. }\end{array}$ & $\begin{array}{l}\text { There was lack of confidence among } \\
\text { GPs about making the diagnosis and } \\
\text { uncertainty about CFS/ME as a medical } \\
\text { condition. Hence, GPs were reluctant to } \\
\text { make the diagnosis of CFS /ME, with } \\
\text { resultant diagnostic delays and lack of } \\
\text { appropriate primary care. }\end{array}$ \\
\hline $\begin{array}{c}\text { Hannon K, Peters S, } \\
\text { Fisher L, Riste L, } \\
\text { Wearden A, Lovell K, } \\
\text { Turner P, Leech Y, } \\
\text { Chew-Graham C [34] }\end{array}$ & 2012 & NW England & $\begin{array}{l}\text { Semi-structured } \\
\text { interviews with patients, } \\
\text { carers, practice nurses, } \\
\text { ME/CFS specialists and } \\
\text { GPs }\end{array}$ & 9 & $\begin{array}{l}\text { Acquisition of information } \\
\text { with the intention of } \\
\text { developing a training resource } \\
\text { on ME/CFS for primary care. }\end{array}$ & $\begin{array}{l}\text { The GPs had varying degrees of } \\
\text { understanding of ME/CFS; some } \\
\text { questioned whether ME/CFS was a } \\
\text { legitimate illness, and were unaware of } \\
\text { the evidence base. There was concern } \\
\text { about difficulties of referral to } \\
\text { secondary care due to fragmented } \\
\text { services and lack of collaboration. }\end{array}$ \\
\hline
\end{tabular}


Table 6. Cont.

\begin{tabular}{|c|c|c|c|c|c|c|}
\hline Authors & $\begin{array}{c}\text { Year of } \\
\text { Publication }\end{array}$ & Location & Methodology & GP Sample Size & Relevant Outcome Measures & Findings \\
\hline $\begin{array}{c}\text { Bayliss K; Riste L; Fisher } \\
\text { L; Wearden A; Peters S; } \\
\text { Lovell K; Chew-Graham } \\
\text { C [35] }\end{array}$ & 2014 & NW England & $\begin{array}{c}\text { Semi-structured } \\
\text { interviews with key } \\
\text { stakeholders (11 BME } \\
\text { patients, } 2 \text { carers, } 9 \text { GPs, } \\
5 \text { practice nurses, } 4 \\
\text { ME/CFS specialists, } 5 \\
\text { BME community } \\
\text { leaders) }\end{array}$ & 9 & $\begin{array}{l}\text { Key themes identified were: } \\
\text { models of illness, access to } \\
\text { care, language and } \\
\text { understanding, family and } \\
\text { community, religion and } \\
\text { culture, stereotypes and } \\
\text { racism. }\end{array}$ & $\begin{array}{l}\text { Patients tended to be unwilling to } \\
\text { consult GPs for fatigue, and also } \\
\text { encountered impediments to accessing } \\
\text { primary care. The high turnover of } \\
\text { inner-city GPs may constitute a barrier } \\
\text { to accessing care. }\end{array}$ \\
\hline $\begin{array}{c}\text { Bayliss K, Riste L, Band } \\
\text { R, Peters S, Wearden A, } \\
\text { Lovell K, Fisher L, } \\
\text { Chew-Graham CA [36] }\end{array}$ & 2016 & NW England & $\begin{array}{l}\text { Semi-structured } \\
\text { interviews with GPs } \\
\text { taking part in an } \\
\text { ME/CFS training } \\
\text { programme }\end{array}$ & 28 & $\begin{array}{l}\text { GPs' experience of managing } \\
\text { people with CFS/ME before } \\
\text { participating in the study, and } \\
\text { their opinions on the training } \\
\text { programme. }\end{array}$ & $\begin{array}{l}\text { There was difficulty recruiting GP } \\
\text { practices, for reasons including } \\
\text { scepticism about ME/CFS, the } \\
\text { complexity of managing the condition, } \\
\text { lack of time in a } 10 \text { min consultation, } \\
\text { and limited specialist referral options. }\end{array}$ \\
\hline
\end{tabular}

Table 7. Qualitative studies of patients' views of GPs' knowledge and understanding of ME/CFS.

\begin{tabular}{|c|c|c|c|c|c|c|}
\hline Authors & $\begin{array}{c}\text { Year of } \\
\text { Publication }\end{array}$ & Location & Methodology & $\begin{array}{c}\text { Patient Sample } \\
\text { Size }\end{array}$ & Relevant Outcome Measures & Findings \\
\hline $\begin{array}{l}\text { Denz-Penhey H, } \\
\text { Murdoch JC [31] }\end{array}$ & 1993 & New Zealand & $\begin{array}{l}\text { Action research in a } \\
\text { general practice }\end{array}$ & 10 & $\begin{array}{l}\text { What patients expected of } \\
\text { their GPs. }\end{array}$ & $\begin{array}{l}\text { Patients primarily sought legitimation, } \\
\text { and acknowledgement of the illness } \\
\text { (i.e., acceptance, diagnosis, support), } \\
\text { symptom control, recommendations } \\
\text { regarding health behaviours, and } \\
\text { relapse prevention. There was much } \\
\text { dissatisfaction with GPs' perceived } \\
\text { failure to meet patients' needs. }\end{array}$ \\
\hline
\end{tabular}


Table 7. Cont.

\begin{tabular}{|c|c|c|c|c|c|c|}
\hline Authors & $\begin{array}{c}\text { Year of } \\
\text { Publication }\end{array}$ & Location & Methodology & $\begin{array}{c}\text { Patient Sample } \\
\text { Size }\end{array}$ & Relevant Outcome Measures & Findings \\
\hline Ax S; Gregg VH; Jones D. & 1997 & London, U.K. & $\begin{array}{l}\text { Semi-structured } \\
\text { interviews }\end{array}$ & 18 & $\begin{array}{l}\text { Illness beliefs, meaning of the } \\
\text { diagnosis and satisfaction } \\
\text { with medical support. }\end{array}$ & $\begin{array}{l}\text { Most participants found that GP } \\
\text { emotional and informational support } \\
\text { was inadequate, and they felt } \\
\text { unsupported. This was coupled with } \\
\text { the rejection of medical and health } \\
\text { professionals and an increased sense of } \\
\text { self-reliance. }\end{array}$ \\
\hline $\begin{array}{c}\text { Saltzstein BJ, Wyshak G, } \\
\text { Hubbuch JT, Perry JC } \\
\text { [42] }\end{array}$ & 1998 & U.S.A. & $\begin{array}{l}\text { Semi-structured } \\
\text { interviews }\end{array}$ & 15 & $\begin{array}{l}\text { Self-report v. perception of } \\
\text { physician's prognosis }\end{array}$ & $\begin{array}{l}\text { Improvement in health appeared } \\
\text { associated with early diagnosis and a } \\
\text { physician optimistic about prognosis }\end{array}$ \\
\hline $\begin{array}{c}\text { Chew-Graham CA; } \\
\text { Cahill G; Dowrick C; } \\
\text { Wearden A; Peters S [43] }\end{array}$ & 2008 & NW England & $\begin{array}{c}\text { Semi-structured } \\
\text { interviews with patients } \\
\text { participating in a } \\
\text { primary care-based } \\
\text { randomised } \\
\text { controlled trial (the FINE } \\
\text { Trial) }\end{array}$ & 24 & $\begin{array}{l}\text { Key emergent themes: }(1) \\
\text { understanding CFS /ME and } \\
\text { management, and (2) } \\
\text { accessing alternative sources } \\
\text { of evidence. }\end{array}$ & $\begin{array}{l}\text { Patients were aware of the risk to their } \\
\text { credibility from GPs who may not have } \\
\text { accepted that ME/CFS even existed as a } \\
\text { genuine diagnosis, and were also aware } \\
\text { of the limitations of many GPs' } \\
\text { knowledge of the condition. }\end{array}$ \\
\hline $\begin{array}{l}\text { Chew-Graham C; Brooks } \\
\text { J; Wearden A; Dowrick } \\
\text { C; Peters S [44]. }\end{array}$ & 2011 & NW England & $\begin{array}{c}\text { Semi-structured } \\
\text { interviews with patients } \\
\text { participating in a } \\
\text { primary care-based } \\
\text { randomised } \\
\text { controlled trial (the FINE } \\
\text { Trial) }\end{array}$ & 19 & $\begin{array}{l}\text { Emergent themes: feeling } \\
\text { accepted and believed by the } \\
\text { therapist, their own } \\
\text { acceptance of the diagnosis, } \\
\text { and accepting the model of } \\
\text { illness presented by the } \\
\text { therapist. }\end{array}$ & $\begin{array}{l}\text { Engagement of patients with pragmatic } \\
\text { rehabilitation in primary care depends } \\
\text { on whether they feel accepted and } \\
\text { believed, accept the diagnosis, and have } \\
\text { an illness model consistent with the } \\
\text { treatment. }\end{array}$ \\
\hline $\begin{array}{l}\text { Gilje AM; Soderlund A; } \\
\text { Malterud K. [45]. }\end{array}$ & 2008 & Norway & $\begin{array}{l}\text { Questionnaire and } \\
\text { follow-up meeting }\end{array}$ & 12 & $\begin{array}{c}\text { Exploration of patients' views } \\
\text { about the impact of negative } \\
\text { opinions held by doctors. }\end{array}$ & $\begin{array}{l}\text { Lack of GP belief in or } \\
\text { acknowledgement of the reality of the } \\
\text { illness can be worse for patients than } \\
\text { the illness itself. Participants wanted } \\
\text { doctors to question, listen and take } \\
\text { them seriously. GPs were perceived as } \\
\text { knowing little about ME/CFS, and } \\
\text { therefore unable to give advice. }\end{array}$ \\
\hline
\end{tabular}


Table 7. Cont

\begin{tabular}{|c|c|c|c|c|c|c|}
\hline Authors & $\begin{array}{c}\text { Year of } \\
\text { Publication }\end{array}$ & Location & Methodology & $\begin{array}{c}\text { Patient Sample } \\
\text { Size }\end{array}$ & Relevant Outcome Measures & Findings \\
\hline $\begin{array}{c}\text { Hannon K, Peters S, } \\
\text { Fisher L, Riste L, } \\
\text { Wearden A, Lovell K, } \\
\text { Turner P, Leech Y, } \\
\text { Chew-Graham C [34] }\end{array}$ & 2012 & NW England & $\begin{array}{l}\text { Semi-structured } \\
\text { interviews with patients, } \\
9 \text { of whom were from } \\
\text { BME communities. }\end{array}$ & 16 & $\begin{array}{l}\text { Key themes identified were } \\
\text { the need to be believed, the } \\
\text { importance of a positively } \\
\text { framed diagnosis, defining, } \\
\text { prioritising, and managing } \\
\text { symptoms, maximising the } \\
\text { benefit of consultation, and } \\
\text { the role of carers. }\end{array}$ & $\begin{array}{l}\text { Patients expressed frustration when } \\
\text { GPs challenged the legitimacy of the } \\
\text { condition, and failed to recognise its } \\
\text { seriousness, or how it can affect } \\
\text { articulateness and memory. Patients felt } \\
\text { a need for signposting, but GPs lacked } \\
\text { knowledge of the condition and } \\
\text { relevant contacts. }\end{array}$ \\
\hline $\begin{array}{c}\text { Bayliss K; Riste L; Fisher } \\
\text { L; Wearden A; Peters S; } \\
\text { Lovell K; Chew-Graham } \\
\text { C [35] }\end{array}$ & 2014 & NW England & $\begin{array}{c}\text { Semi-structured } \\
\text { interviews with key } \\
\text { stakeholders (11 BME } \\
\text { patients, } 2 \text { carers, } 9 \text { GPs, } \\
5 \text { practice nurses, } 4 \\
\text { ME/CFS specialists, } 5 \\
\text { BME community } \\
\text { leaders) }\end{array}$ & 11 & $\begin{array}{c}\text { Themes raised by patients } \\
\text { included: } \\
\text { GPs' perceptions; } \\
\text { patients' lack of awareness of } \\
\text { ME/CFS; } \\
\text { community pressures. }\end{array}$ & $\begin{array}{l}\text { Patients perceived a lack of focus by } \\
\text { GPs on non-specific symptoms, lack of } \\
\text { continuity among city-centre GPs, } \\
\text { negative experiences with GPs (e.g., } \\
\text { seeing some BME people as 'work shy'). } \\
\text { BME GPs seen as less likely to diagnose } \\
\text { ME/CFS. } \\
\text { Community pressures include language } \\
\text { barriers; family pressures, e.g., to be a } \\
\text { high achiever; the influence of religion, } \\
\text { so that some would turn to religion or } \\
\text { spiritual healers rather than primary } \\
\text { care. GPs considered unaware of this. }\end{array}$ \\
\hline $\begin{array}{c}\text { Bayliss K, Riste L, Band } \\
\text { R, Peters S, Wearden A, } \\
\text { Lovell K, Fisher L, } \\
\text { Chew-Graham CA [36] }\end{array}$ & 2016 & NW England & $\begin{array}{l}\text { Semi-structured } \\
\text { interviews with GPs } \\
\text { taking part in an } \\
\text { ME/CFS training } \\
\text { programme }\end{array}$ & 57 & $\begin{array}{l}\text { The enquiry centres on the } \\
\text { extent of agreement between } \\
\text { patients and GPs about how } \\
\text { and by whom ME/CFS should } \\
\text { be managed in primary care, } \\
\text { what is needed to be done to } \\
\text { achieve collaboration between } \\
\text { patients and GPs, and how the } \\
\text { training programme should be } \\
\text { assessed. }\end{array}$ & $\begin{array}{l}\text { Patients felt that ME/CFS should be } \\
\text { managed within primary care, but } \\
\text { wanted to be believed and to receive a } \\
\text { positive diagnosis. Where this did not } \\
\text { happen, patients disengaged from } \\
\text { primary care, illustrating the tension } \\
\text { between their needs and barriers to care } \\
\text { perceived by GPs, including the } \\
\text { inadequacy of a ten-minute } \\
\text { consultation for such a complex illness. }\end{array}$ \\
\hline
\end{tabular}




\section{Discussion}

The quantitative surveys of GPs were carried out over a fourteen-year period, and are consistent in demonstrating that a substantial proportion of GPs, which changed little over that time, did not accept ME/CFS as a genuine clinical entity. In addition, it is clear that many GPs, even when they accept that ME/CFS is real, lack confidence in diagnosing or managing it. There is a similar degree of consistency in the surveys of patients with clinically confirmed ME/CFS. Despite differences in geographical location, they again report degrees of criticism of aspects of GP care which are similar in magnitude. Other reviewed quantitative studies suggested that diagnostic fashion played a part in GP diagnosis, that there were substantial delays in diagnosing ME/CFS in primary care in children, and that the problem of lack of recognition of ME/CFS was geographically widespread despite cultural differences between different countries.

Similarly, the qualitative studies of GPs, despite differences in geographical location and methodology, were consistent in demonstrating marked gaps in GPs' knowledge and the understanding of ME/CFS. The extremely heterogeneous studies of patients all came to similar conclusions: that there were problems for patients over legitimation of the illness, and over lack of sympathy and knowledge among GPs. The reviewed overview papers acknowledged that ME/CFS was poorly understood in primary care, but that ME/CFS was best managed by GPs, who needed to show respect for patients and humility.

The strengths of the study are firstly that we were able to perform a wide-ranging review of the literature, including qualitative, quantitative and mix-methods research, from both the GP and the patient perspectives. Secondly, we were able to take a methodologically rigorous approach, following the SWiM methodology. The weakness of the study was that, because of the heterogeneity of the literature identified, we were not able to perform a systematic review, and we were unable to carry out a meta-synthesis of the qualitative papers, or a meta-analysis of the quantitative papers. It is also possible that some papers may have been missed by our search.

The studies of both GPs and patients all point in the same direction. Many doctors display uncertainty about whether ME/CFS is a real illness, either not having been trained in it or refusing to recognise ME/CFS as a genuine clinical entity, with consequent delays in diagnosis and treatment for patients. Patients with ME/CFS, for their part, often experience suspicion from healthcare professionals and resultant marginalisation, which represents professional failure, with ethical and practical consequences for care and treatment [46]. There are other pointers in the research literature, in addition to those papers identified in our MEDLINE search, which lead to the same conclusions. For example, a Dutch study of the prevalence of ME/CFS-like illness in the working population concluded that such illness may be under-detected in the working population and perhaps in other populations as well [47]. An English study assessing the feasibility of a randomised controlled trial of an early intervention for ME/CFS in primary care concluded that this was not feasible, partly because of evidence of GPs' difficulties in diagnosing ME/CFS and managing the condition [48].

The factors underlying under-ascertainment of ME/CFS are complex and multiple. The mistaken conclusion $[49,50]$ that an early recorded manifestation of epidemic ME/CFS, Royal Free disease, was epidemic hysteria [51] has coloured thinking for half a century, with its insistence on the biopsychosocial hypothesis that ME/CFS can be totally explained away as being due to faulty illness beliefs combined with deconditioning. This has been important in creating disbelief and uncertainty among healthcare professionals in respect of diagnosis, living with ME/CFS, treatment and management, professional values, and support for people with ME/CFS, with insufficient importance attached to listening skills and to establishing a therapeutic relationship [52]. Such controversies surrounding the diagnosis have led to tension between patients and healthcare professionals [53], and the helplessness many GPs feel because of their lack of knowledge of ME/CFS leads to avoidance and neglect [54]. 
The consequences of under-ascertainment, and the lack of services to treat ME/CFS, contributes to patient stress and depression, which is frequently associated with fatigue [55]. Diagnostic delay is a risk factor for severe disease (i.e., rendering the patient housebound or bedbound) [56], and such patients may lie at home without having seen a doctor for many years. Furthermore, diagnostic failures in primary care affect outcomes adversely; for example, it has been shown that failure to diagnose primary sleep disorders in individuals with ME/CFS may be implicated in the development of psychological disturbances [57].

Many of the papers in this review were published some years ago, but there is evidence in the grey literature that very little has changed. A survey of members of the Oxfordshire ME supporters' group in England (OMEGA) in 2012 reported that, of the 56 who responded, all had been diagnosed with ME/CFS, half of them (28) by a GP. However, only 10 had seen their GP in the month prior to completing the questionnaire. Only 27\% of OMEGA members surveyed found their GP to be either helpful or most helpful. The report's author commented that "listening to the patient, believing what they say and coming to an accurate diagnosis would seem to be the most basic starting point for any effective treatment or help. However, this is not the case for many ME/CFS patients. 39\% mentioned lack of diagnosis and belief as the most unhelpful thing". Uninformed, negative or hostile attitudes from healthcare professionals are very stressful and detrimental to the health and well-being of people with ME/CFS, and could deter them from seeking treatment. Patients had low expectations of their GPs, and frequently failed to receive good advice or effective symptom control because of a lack of information on the part of GPs. They themselves have identified this as a problem, although most GPs (93\%) recognised ME/CFS as a genuine clinical entity. Three-quarters (74\%) of GPs recognised the need for better information and training about diagnosis and treatment, and the availability of local services. Uninformed, negative, or hostile attitudes to people with ME/CFS from healthcare professionals were very stressful and detrimental to health and well-being, and could deter them from seeking treatment [58].

An unpublished survey was conducted in 2018 in the U.K. of 44 hospital doctors attending a regional training event. They completed a questionnaire, the responses to which showed that $72 \%$ did not know how to diagnose ME, while $76 \%$ lacked confidence in dealing with ME patients. Eighty-two percent of respondents believed ME to be at least in part a psychological or psychosomatic problem, while 39\% did not realise that post exertional malaise is an essential requirement for the diagnosis of ME [59].

Other evidence has been provided in a report from the European Federation of Neurological Associations (EFNA), which published a survey on stigma and neurological disorder. There were 1373 responses to the survey; 402 of these were received from people with ME/CFS, many of whom felt stigmatised in their interactions with medical professionals. A total of $74 \%$ felt that a medical professional did not believe the extent or severity of their symptoms, and the same percentage felt that they did not receive adequate or appropriate treatment because a medical professional did not take them seriously. Stigma was also widespread within families and in social situations. Forty-nine percent said that their families sometimes make them feel that they exaggerate their condition and, sadly, $32 \%$ of respondents with children have been made to feel that they are inadequate parents. Almost half of respondents who lived with a neurological disorder during childhood found it difficult to make friends or maintain friendships at school, and a similar number were excluded from school events on account of their condition [60].

Finally, in an Australian survey of 1055 people with ME, 70\% expressed a wish for better-informed GPs, and $48 \%$ of respondents said their GPs were poorly or very poorly informed, compared with $44 \%$ in 2015 . Only $29 \%$ of respondents stated that their GPs were well or very well informed, and only $31 \%$ regarded health professionals as a key source of information about ME/CFS [61].

The quantitative studies of GP attitudes in the U.K., which demonstrated a considerable degree of scepticism about ME/CFS, were undertaken in the aftermath of the publication of the report of the U.K. Chief Medical Officer's working party on ME/CFS, 
which had confirmed its existence as a genuine clinical entity [62]. This suggests that the impact of that report on a substantial body of medical opinion was minimal, which is disappointing. The qualitative studies, and studies involving patients, from a wider time scale and range of geographical locations, suggest that such attitudes are by no means confined to the U.K., and remain widespread. The lack of undergraduate and postgraduate teaching on ME/CFS for medical students and doctors may account in large measure for the persistence of such attitudes, and, in a parallel study, we have investigated the current status of medical education on ME/CFS across Europe, as well as possible solutions to the problem.

\section{Conclusions}

Between a third and a half of GPs lack confidence in diagnosing or managing ME/CFS, or dispute its existence as a genuine clinical entity. A similar proportion of ME/CFS patients express dissatisfaction with the primary medical care they have received, and experienced marked diagnostic delay when they first fell ill. These proportions have changed little over recent years, and similar conclusions have been reached across the range of geographical locations where these matters have been investigated. This conclusion renders problematic attempts to determine the prevalence of ME/CFS, and hence its economic impact. In addition, diagnostic delay is associated with severe disease and poor prognosis, and the likelihood of increased costs.

Author Contributions: Conceptualisation, all authors; methodology, D.A.H. and D.F.H.P.; validation, all authors.; formal analysis, D.F.H.P.; investigation, D.A.H., D.F.H.P. and X.W.-S.; resources, D.A.H., D.F.H.P. and X.W.-S.; writing—original draft preparation, D.F.H.P.; writing—review and editing, J.C., D.F.H.P., J.-D.d.K., D.A.H. and L.G.; visualization, all authors.; project administration, D.F.H.P. All authors have read and agreed to the published version of the manuscript.

Funding: This research received no external funding. EUROMENE receives funding for networking activities from the COST programme (COST Action 15111), via the COST Association.

Institutional Review Board Statement: Not applicable.

Informed Consent Statement: Not applicable.

Data Availability Statement: No new data were created or analysed in this study. Data sharing is not applicable to this article.

Conflicts of Interest: The authors declare no conflict of interest.

\section{References}

1. Lindan, R. Benign Myalgic Encephalomyelitis. Can. Med. Assoc. J. 1956, 75, 596-597.

2. Acheson, E.D. The clinical syndrome variously called myalgic encephalomyelitis, Iceland disease and epidemic neuromyasthenis. Am. Med. 1959, 26, 589-595. [CrossRef]

3. Carruthers, B.M.; Jain, A.K.; De Meirleir, K.L.; Peterson, D.L.; Klimas, N.G.; Lerner, A.M.; Sherkey, J.A. Myalgic encephalomyelitis/chronic fatigue syndrome: Clinical working case definition, diagnostic and treatment protocols. J. Chronic Fatigue Syndr. 2003, 11, 7-116. [CrossRef]

4. Johnstone, S.C.; Staines, D.R.; Marshall-Gradisnik, S.M. Epidemiological characteristics of chronic fatigue syndrome/myalgic encephalomyelitis in Australian patients. Clin. Epidemiol. 2016, 8, 97-107. [CrossRef]

5. Pheby, D.; Lacerda, E.; Nacul, L.; de Lourdes Drachler, M.; Campion, P.; Howe, A.; Sakellariou, D. A disease register for ME/CFS: Report of a pilot study. BMC Res. Notes 2011, 4, 139-146. [CrossRef]

6. Lloyd, A.R.; Hickie, I.; Boughton, C.R.; Wakefield, D.; Spencer, O. Prevalence of chronic fatigue syndrome in an Australian population. Med. J. Aust. 1990, 153, 522-528. [CrossRef]

7. Action for ME. Available online: https://actionforme.org.uk/what-is-me/introduction/. (accessed on 6 January 2020).

8. EUROMENE. Available online: http:/ / euromene.eu/ (accessed on 13 October 2020).

9. Pheby, D.F.; Arāja, D.; Berkis, U.; Brenna, E.; Cullinan, J.; De Korwin, J.-D.; Gitto, L.; Hughes, D.; Hunter, R.; Trepel, D.; et al. The development of a consistent Europe-wide approach to investigating the economic impact of myalgic encephalomyelitis (ME/CFS): A report from the European Network on ME/CFS (EUROMENE). Healthcare 2020, 8, 88. [CrossRef]

10. COST Action 15111_EUROMENE (European ME/CFS Research Network), Working Group 3: Socio-Economics. Deliverable 10-Common consensus protocol for economic loss calculation due to ME/CFS. Brussels. September 2019. Available online: http:/ / euromene.eu/workinggroups/deliverables/deliverable.html (accessed on 14 October 2020). 
11. Bayliss, K.; Goodall, M.; Chisholm, A.; Fordham, B.; Chew-Graham, C.; Riste, L.; Fisher, L.; Lovell, K.; Peters, S.; Wearden, A.J. Overcoming the barriers to the diagnosis and management of chronic fatigue syndrome/ME in primary care: A meta synthesis of qualitative studies. BMC Fam. Pract. 2014, 15, 44. [CrossRef]

12. Campbell, M.; McKenzie, J.E.; Sowden, A.; Katikireddi, S.V.; Brennan, S.E.; Ellis, S.; Hartmann-Boyce, J.; Ryan, R.; Shepperd, S.; Thomas, J.; et al. Synthesis without meta-analysis (SWiM) in systematic reviews: Reporting guideline. BMJ 2020, 368,16890 [CrossRef]

13. Saidi, G.; Haines, L. The management of children with chronic fatigue syndrome-like illness in primary care: A cross-sectional study. Brit. J. Gen. Pract. 2006, 56, 43-47.

14. Thomas, M.; Smith, A.P. Primary healthcare provision and Chronic Fatigue Syndrome: A survey of patients' and General Practitioners' beliefs. BMC Fam. Pract. 2005, 6, 49. [CrossRef]

15. Ho-Yen, D.O.; McNamara, I. General practitioners' experience of the chronic fatigue syndrome. Brit. J. Gen. Pract. 1991, 41, 324-326.

16. Bowen, J.; Pheby, D.; Charlett, A.; McNulty, C. Chronic Fatigue Syndrome: A survey of GPs' attitudes and knowledge. Fam. Pract. 2005, 22, 389-393. [CrossRef]

17. Steven, I.D.; McGrath, B.; Qureshi, F.; Wong, C.; Chern, I.; Pearn-Rowe, B. General practitioners' beliefs, attitudes and reported actions towards chronic fatigue syndrome. Aust. Fam. Physician 2000, 29, 80-85.

18. Bazelmans, E.; Vercoulen, J.; Swanink, C.; Fennis, J.; Galama, J.; Van Weel, C.; Van Der Meer, J.; Bleijenberg, G. Chronic Fatigue Syndrome and Primary Fibromyalgia Syndrome as recognized by GPs. Fam. Pract. 1999, 16, 602-604. [CrossRef]

19. FitzGibbon, E.J.; Murphy, D.; O'Shea, K.; Kelleher, C. Chronic debilitating fatigue in Irish general practice: A survey of general practitioners' experience. Br. J. Gen. Pract. 1997, 47, 618-622.

20. Van Hoof, E. The doctor-patient relationship in chronic fatigue syndrome: Survey of patient perspectives. Qual. Prim. Care 2009, $17,263-270$.

21. Vandenbergen, J.; Vanheule, S.; Desmet, M.; Verhaeghe, P. Unexplained chronic fatigue and interpersonal problems: A study in a primary care population. Int. J. Psychiatry Med. 2009, 39, 325-340. [CrossRef]

22. Cathébras, P.; Jacquin, L.; Le Gal, M.; Fayol, C.; Bouchou, K.; Rousset, H. Correlates of somatic causal attributions in primary care patients with fatigue. Psychother. Psychosom. 1995, 63, 174-180. [CrossRef]

23. Hansen, A.H.; Lian, O.S. Experiences of general practitioner continuity among women with chronic fatigue syndrome/myalgic encephalomyelitis: A cross-sectional study. BMC Health Serv. Res. 2016, 16, 1-8. [CrossRef]

24. Hansen, A.H.; Lian, O.S. How do women with chronic fatigue syndrome/myalgic encephalomyelitis rate quality and coordination of healthcare services? A cross-sectional study. BMJ Open 2016, 6, e010277. [CrossRef] [PubMed]

25. Lian, O.S.; Hansen, A.H. Factors facilitating patient satisfaction among women with medically unexplained long-term fatigue: A relational perspective. Health Interdiscip. J. Soc. Study Health Illn. Med. 2015, 20, 308-326. [CrossRef] [PubMed]

26. Jason, L.A.; Ferrari, J.R.; Taylor, R.R.; Slavich, S.P.; Stenzel, C.L. A national assessment of the service, support, and housing preferences by persons with chronic fatigue syndrome. Toward a comprehensive rehabilitation program. Eval. Health Prof. 1996, 19, 194-207. [CrossRef] [PubMed]

27. Gallagher, A.M.; Thomas, J.M.; Hamilton, W.T.; White, P.D. Incidence of fatigue symptoms and diagnoses presenting in UK primary care from 1990 to 2001. JRSM 2004, 97, 571-575. [CrossRef] [PubMed]

28. Bakken, I.J.; Tveito, K.; Aaberg, K.M.; Ghaderi, S.; Gunnes, N.; Trogstad, L.; Magnus, P.; Stoltenberg, C.; Håberg, S.E. Comorbidities treated in primary care in children with chronic fatigue syndrome / myalgic encephalomyelitis: A nationwide registry linkage study from Norway. BMC Fam. Pract. 2016, 17, 128. [CrossRef]

29. Cho, H.J.; Menezes, P.R.; Hotopf, M.; Bhugra, D.; Wessely, S. Comparative epidemiology of chronic fatigue syndrome in Brazilian and British primary care: Prevalence and recognition. Br. J. Psychiatry 2009, 194, 117-122. [CrossRef]

30. Brimmer, D.J.; McCleary, K.K.; A Lupton, T.; Faryna, K.M.; Hynes, K.; Reeves, W.C. A train-the-trainer education and promotion program: Chronic fatigue syndrome-a diagnostic and management challenge. BMC Med. Educ. 2008, 8, 49. [CrossRef]

31. Denz-Pe nhey, H.; Murdoch, J.C. Service delivery for people with chronic fatigue syndrome: A pilot action research study. Fam. Pract. 1993, 10, 14-18. [CrossRef]

32. Bayliss, K.; Riste, L.; Band, R.; Peters, S.; Wearden, A.; Lovell, K.; Fisher, L.; A Chew-Graham, C. Implementing resources to support the diagnosis and management of Chronic Fatigue Syndrome/Myalgic Encephalomyelitis (CFS/ME) in primary care: A qualitative study. BMC Fam. Pract. 2016, 17, 1-11. [CrossRef]

33. Chew-Graham, C.; Dowrick, C.; Wearden, A.; Richardson, V.; Peters, S. Making the diagnosis of Chronic Fatigue Syndrome/Myalgic Encephalitis in primary care: A qualitative study. BMC Fam. Pract. 2010, 11, 16. [CrossRef]

34. Hannon, K.L.; Peters, S.; Fisher, L.; Riste, L.; Wearden, A.J.; Lovell, K.; Turner, P.; Leech, Y.; Chew-Graham, C. Developing resources to support the diagnosis and management of Chronic Fatigue Syndrome/Myalgic Encephalitis (CFS/ME) in primary care: A qualitative study. BMC Fam. Pract. 2012, 13, 93. [CrossRef] [PubMed]

35. Bayliss, K.; Riste, L.; Fisher, L.; Wearden, A.; Peters, S.; Lovell, K.; Chew-Graham, C. Diagnosis and management of chronic fatigue syndrome/myalgic encephalitis in black and minority ethnic people: A qualitative study. Prim. Health Care Res. Dev. 2013, 15, 143-155. [CrossRef] [PubMed]

36. Raine, R.; Carter, S.; Sensky, T.; Black, N. General practitioners' perceptions of chronic fatigue syndrome and beliefs about its management, compared with irritable bowel syndrome: Qualitative study. BMJ 2004, 328, 1354-1357. [CrossRef] [PubMed] 
37. Bansal, A.S. Investigating unexplained fatigue in general practice with a particular focus on CFS/ME. BMC Fam. Pract. 2016, 17, 81. [CrossRef] [PubMed]

38. Wearden, A.J.; Chew-Graham, C. Managing chronic fatigue syndrome in U.K. primary care: Challenges and opportunities. Chronic Illn. 2006, 2, 143-153. [CrossRef]

39. Murdoch, J.C. Chronic fatigue syndrome. The patient centred clinical method-a guide for the perplexed. Aust. Fam. Physician 2003, 32, 883-887.

40. Campion, P. Chronic fatigue syndrome: Is the biopsychosocial model responsible for patient dissatisfaction and harm? (letter). Br. J. Gen. Pract. 2016, 66, 511. [CrossRef]

41. Ax, S.; Gregg, V.H.; Jones, D. Chronic Fatigue Syndrome: Sufferers' Evaluation of Medical Support. J. R. Soc. Med. 1997, 90, 250-254. [CrossRef]

42. Saltzstein, B.J.; Wyshak, G.; Hubbuch, J.T.; Perry, J.C. A naturalistic study of the chronic fatigue syndrome among women in primary care. Gen. Hosp. Psychiatry 1998, 20, 307-316. [CrossRef]

43. Chew-Graham, C.A.; Cahill, G.; Dowrick, C.; Wearden, A.; Peters, S. Using Multiple Sources of Knowledge to Reach Clinical Understanding of Chronic Fatigue Syndrome. Ann. Fam. Med. 2008, 6, 340-348. [CrossRef]

44. Chew-Graham, C.; Brooks, J.; Wearden, A.; Dowrick, C.; Peters, S. Factors influencing engagement of patients in a novel intervention for CFS/ME: A qualitative study. Prim. Health Care Res. Dev. 2010, 12, 112-122. [CrossRef] [PubMed]

45. Gilje, A.M.; Söderlund, A.; Malterud, K. Obstructions for quality care experienced by patients with chronic fatigue syndrome (CFS)-A case study. Patient Educ. Couns. 2008, 73, 36-41. [CrossRef] [PubMed]

46. Blease, C.; Carel, H.; Geraghty, K. Epistemic injustice in healthcare encounters: Evidence from chronic fatigue syndrome. J. Med. Ethics. 2017, 43, 549-557. [CrossRef]

47. Huibers, M.J.H.; Kant, I.J.; Swaen, G.M.H.; Kasl, S.V. Prevalence of chronic fatigue syndrome-like caseness in the working population: Results from the Maastricht cohort study. Occup. Environ. Med. 2004, 61, 464-466. [CrossRef] [PubMed]

48. O'Dowd, H.; Beasant, L.; Ingram, J.; A Montgomery, A.; Hollingworth, W.W.; Gaunt, D.; Collin, S.M.; Horne, S.; Jones, B.; Crawley, E. The feasibility and acceptability of an early intervention in primary care to prevent chronic fatigue syndrome (CFS) in adults: Randomised controlled trial. Pilot Feasibility Stud. 2020, 6, 65. [CrossRef] [PubMed]

49. Kermack, W.O.; McKendrick, A.G. Contribution to the mathematical theory of epidemics. Proc. R. Soc. London 1927, 772, 701-721.

50. Waters, F.G.; McDonald, G.J.; Banks, S.; Waters, R.A. Myalgic Encephalomyelitis (ME) outbreaks can be modelled as an infectious disease: A mathematical reconsideration of the Royal Free Epidemic of 1955. Fatigue: Biomed. Health Behav. 2020, 8, 70-83. [CrossRef]

51. McEvedy, C.P.; Beard, A.W. Royal Free Epidemic of 1955: A Reconsideration. BMJ 1970, 1, 7-11. [CrossRef]

52. Horton, S.; Poland, F.; Kale, S.; Drachler, M.D.L.; Leite, J.C.D.C.; McArthur, M.; Campion, P.; Pheby, D.; Nacul, L. Chronic fatigue syndrome/myalgic encephalomyelitis (CFS/ME) in adults: A qualitative study of perspectives from professional practice. BMC Fam. Pract. 2010, 11, 89. [CrossRef]

53. Nacul, L.; Lacerda, E.M.; Kingdon, C.C.; Curran, H.; Bowman, E.W. How have selection bias and disease misclassification undermined the validity of myalgic encephalomyelitis/chronic fatigue syndrome studies? J. Health Psychol. 2019, 24, 1765-1769. [CrossRef]

54. Speight, N. Severe ME in Children. Healthcare 2020, 8, 211. [CrossRef]

55. Stadje, R.; Dornieden, K.; Baum, E.; Becker, A.; Biroga, T.; Bösner, S.; Haasenritter, J.; Keunecke, C.; Viniol, A.; Donner-Banzhoff, N. The differential diagnosis of tiredness: A systematic review. BMC Fam. Pract. 2016, 17, 147. [CrossRef]

56. Pheby, D.; Saffron, L. Risk factors for severe ME/CFS. Biol. Med. 2009, 1, 50-74.

57. Fossey, M.; Libman, E.; Bailes, S.; Baltzan, M.; Schondorf, R.; Amsel, R.; Fichten, C.S. Sleep quality and psychological adjustment in chronic fatigue syndrome. J. Behav. Med. 2004, 27, 581-605. [CrossRef]

58. Oxfordshire ME Group for Action (OMEGA). OMEGA Membership Survey on Local NHS Services for ME/CFS (April 2013). Available online: http:/ / omegaoxon.org/publications (accessed on 22 July 2020).

59. Hng, K.N. Doctors' Knowledge and Understanding of Myalgic Encephalomyelitis—United Kingdom. 2018. Available online: https: / / bit.ly/2yFAtY8 or https: / / bit.ly/3byfwga (accessed on 14 October 2020).

60. European Federation of Neurological Associations [EFNA-] 2020-Survey on Stigma and Neurological Disorder. Available online: https: / www.efna.net/survey2020/ (accessed on 22 July 2020).

61. Anon. Lifelong Lockdown: Lessons Learned from the Health and Wellbeing Survey of Australians Living with ME/CFS 2019. Emerge Australia, October 2020. Available online: https:/ / www.emerge.org.au/health-and-wellbeing-survey-2019 (accessed on 14 October 2020).

62. CFS/ME Working Group. Report to the Chief Medical Officer of an Independent Working Group; Department of Health: London, UK, 2001. 